\title{
PERANAN MEDIA VISUAL GAMBAR DALAM PROSES BELAJAR MENGAJAR UNTUK MENINGKATKAN HASIL BELAJAR SISWA KELAS \\ III SEKOLAH DASAR NEGERI GEMBONGAN 04 KECAMATAN \\ PONGGOK KABUPATEN BLITAR JAWA TIMUR
}

\author{
Budhi Irawan, Mujiyanto, Ngadat \\ STABN Negeri Raden Wijaya Jawa Tengah
}

\begin{abstract}
The teaching and learning process of the subject of Buddhist education at Gembongan State Elementary School 04 class III in the use of visual visual media is not optimal. In addition, the teacher in the learning process only uses the lecture method. As a result, the teaching and learning process occurs only in one direction, students become less active, and student learning outcomes become less than optimal. This is the background of the author to conduct research with the aim that the role of visual media images can improve student learning outcomes. This research is a type of classroom action research (CAR) conducted at Gembongan 04 State Elementary School, Ponggok District, Blitar Regency, East Java. The research class used was class III. This study consisted of two learning cycles, each cycle consisting of two meetings. In addition to controlling the learning activities, several instruments were used, namely observation sheets, interview guidelines, and test questions. The results showed that the learning outcomes of third grade students at Gembongan 04 Public Elementary School, Ponggok District, Blitar Regency, East Java had increased using the role of visual visual media. Improved mastery learning outcomes from Cycle I by $43 \%$. Then in Cycle II an increase of 100\%. This shows an increase of 57\%. In addition to improved learning outcomes, the students' learning process shows activity, students appear to be more happy and enthusiastic.
\end{abstract}

Keywords: Learning Outcomes, Image Visual Media

\begin{abstract}
ABSTRAK
Proses belajar mengajar mata pelajaran pendidikan agama Buddha Sekolah Dasar Negeri Gembongan 04 kelas III dalam penggunaan media visual gambar belum optimal. Selain itu, guru dalam proses belajar mengajar hanya menggunakan metode ceramah. Akibatnya, proses belajar mengajar hanya terjadi satu arah, siswa menjadi kurang aktif, dan hasil belajar siswa menjadi kurang maksimal. Hal ini yang melatar belakangi penulis untuk melakukan penelitian dengan tujuan bahwa dengan peranan media visual gambar dapat meningkatkan hasil belajar siswa. Penelitian ini merupakan jenis penelitian tindakan kelas (PTK) yang dilakukan di Sekolah Dasar Negeri Gembongan 04 Kecamatan Ponggok Kabupaten Blitar Jawa Timur. Kelas penelitian yang digunakan adalah kelas III. Penelitian ini terdiri dari dua siklus pembelajaran, setiap siklus terdiri dari dua kali pertemuan. Selain itu juga untuk mengontrol kegiatan pembelajaran digunakan beberapa instrumen, yaitu lembar observasi, pedoman wawancara, dan soal tes. Hasil penelitian menunjukkan bahwa hasil belajar siswa kelas III Sekolah Dasar Negeri Gembongan 04 Kecamatan Ponggok Kabupaten Blitar Jawa Timur sudah mengalami peningkatan dengan menggunakan peranan media visual gambar. Peningkatan ketuntasan hasil belajar dari Siklus I sebesar 43\%. Selanjutnya pada Siklus II terjadi peningkatan 100\%. Hal ini menunjukkan terjadi peningkatan sebesar 57\%. Selain hasil belajar yang meningkat, pada proses belajar mengajar siswa menunjukkan keaktifan, siswa tampak lebih senang dan antusias.
\end{abstract}

Kata kunci: Hasil Belajar, Media Visual Gambar 


\section{PENDAHULUAN}

Tujuan pendidikan di Indonesia adalah mencerdaskan masyarakat Indonesia. Tujuan tersebut tertuang dalam alinia ke-4 pembukaan Undang-undang tahun 1945 (Dwi Winarno, 2006: 110). Melihat tujuan pendidikan tersebut diperlukan proses pembelajaran agar mencapai hasil yang maksimal dan memuaskan. Pencapaian hasil belajar yang maksimal dibutuhkan usaha yang keras dari guru, siswa dan sekolah yang bersangkutan. Keberhasilan siswa dalam pembelajaran dapat dicapai jika proses belajar mengajar berjalan dengan baik.

Proses belajar sebagai aspek yang penting dari lingkungan sekolah. Lingkungan sekolah diatur, diawasi agar kegiatan belajar terarah sesuai dengan tujuan pendidikan. Lingkungan belajar yang baik adalah lingkungan yang mendukung dan merangsang siswa untuk belajar, memberikan rasa nyaman, dan kepuasan serta mencapai tujuan yang diharapkan seperti PP No. 32 tahun 2013 tentang Standar Nasional Pendidikan menyatakan bahwa:

Proses pembelajaran pada satuan pendidikan diselenggarakan secara interaktif, inspiratif, menyenangkan, menantang, memotivasi siswa untuk berpatisipasi aktif serta memberikan ruang yang cukup bagi kreatifitas dan kemandirian sesuai dengan bakat, minat, dan perkembangan fisik serta psikologis siswa.

Pendidikan agama bertujuan untuk membentuk akhlak dan kepribadian peserta didik tidak hanya mencakup hal-hal yang bersifat teoritis atau test book tetapi mencakup juga tentang tingkah laku, sikap dan kepribadian dalam kehidupan sehari-hari, yaitu meliputi ucapan atau perkataan dan perbuatan. sehingga peserta didik Asosiasi Dosen \& Unit Penelitian dan Pengabdian Masyarakat berhak mendapatkan pelajaran, termasuk pendidikan mata pelajaran pendidikan agama Buddha (Rusidi, 2009:167-168).

Pembelajaran dikatakan berhasil jika siswa mampu mencapai kompetensi dasar yang dijabarkandalam indikator-indikator. Keberhasilan pencapaian tujuan pembelajaran dipengaruhi oleh unsur-unsur pembelajaran. Beberapa unsur penting dalam kegiatan pembelajaran, yaitu: guru, siswa, materi pembelajaran, lingkungan, media, model, strategi pembelajaran, dan sarana dan prasarana yang mendukung pembelajaran.

Salah satu unsur terpenting dalam pembelajaran adalah media yang digunakan di sekolah. Penggunaan media pembelajaran dalam proses belajar mengajar di sekolah membantu meningkatkan hasil belajar yang lebih baik. Syaiful Bahri Djamarah \& Zain Aswan (2006: 120) menyatakan bahwa penggunaan media merupakan sumber belajar dalam proses belajar mengajar, kehadiran media mempunyai peranan yang sangat penting. Media pembelajaran menjadi sarana untuk memperjelas materi sehingga materi menjadi jelas dan mudah dipahami oleh siswa.

Pemilihan media yang efektif dapat mendukung dan kelancaran dalam proses belajar mengajar sehingga tercapainya suatu tujuan. Pemilihan media yang efektif dalam pembelajaran yang tepat atau sesuai dengan bahan pelajaran meningkatkan kegiatan belajar siswa. Penggunaan media pembelajaran tersebut adalah penyerangaman materi pembelajaran, proses pembelajaran menjadi lebih jelas dan menarik, pembelajaran lebih interaktif, efisien waktu dan tenaga. Pembelajaran lebih menarik bagi siswa sehingga akan lebih mudah dalam meningkatkan hasil pembelajaran. 
Guru perlu memiliki kemampuan dasar untuk menciptakan pembelajaran yang menarik, diantaranya kemampuan menguasai dan menyampaikan materi, kemampuan menyusun strategi pembelajaran serta kemampuan memilih metode dan media yang tepat dalam mengajar (Fuad Ihsan, 2005: 112-113). Media pembelajaran merupakan salah satu komponen pembelajaran yang mempunyai peranan penting dalam kegiatan belajar mengajar. Pemanfaatan media seharusnya merupakan hal yang perlu diperhatikan guru dalam setiap proses belajar mengajar. Dengan demikian guru harus mempelajari bagaimana memilih media pembelajaran yang tepat agar dapat efektif dalam proses belajar mengajar.

Fakta dilapangan terdapat guru yang belum menggunakan media dalam proses belajar mengajar secara optimal, hal ini disebabkan guru kurang menguasai media. Selain itu guru berpandangan bahwa dengan menggunakan media membutuhkan waktu yang lama dan biaya mahal. Banyak metode pembelajaran yang dapat diterapkan oleh guru untuk mencapai hasil belajar yang maksimal. Metode yang diterapkan guru membantu guru dalam menyampaikan materi pembelajaran. Penggunaan metode yang kurang sesuai dapat mengakibatkan siswa kurang memahami materi yang disampaikan.

Salah satu contoh, seorang guru hanya menggunakan metode ceramah saja, monoton. Guru belum mencoba menerapkan media dalam proses belajar mengajar. Guru menjelaskan, siswa mendengar, guru bercerita, siswa membayangkan, guru mendongeng siswa terpejam matanya, guru menyuruh, siswa menjalankan tugas, tanpa memperhatikan siswanya sudah memahami pembelajaran atau belum. Penyajian materi dengan menggunakan metode ceramah pada umumnya bersifat penyajian secara massal. Pembelajaran yang monoton dengan metode ceramah akan berakibat berkurangnya keaktifan siswa. Hal tersebut berdampak negatif pada siswa, yaitu siswa mudah menjadi jenuh, dan mengantuk pada saat pembelajaran, siswa cenderung merasa tidak nyaman dan pembelajaran menjadi tidak menyenangkan.

Salah satu upaya untuk meningkatkan hasil belajar siswa yaitu dengan menggunakan metode yang tepat dalam proses belajar mengajar. Selain menggunakan metode yang tepat, guru juga menggunakan media dalam proses belajar mengajar secara optimal, karena tanpa media yang tepat dalam proses belajar mengajar mengakibatkan hasil belajar siswa kurang maksimal. Menurut Oemar Hamalik (2003:155) hasil belajar adalah sebagai terjadinya perubahan tingkah laku pada diri seseorang yang dapat di amati dan diukur bentuk pengetahuan, sikap dan keterampilan.

Manusia yang telah terbebas dari kekotoran batin mencapai tingkat kesucian Arahatta Phala disebut sebagai manusia yang telah mencapai nibbana, pencapaian nibbana yaitu berakhirnya segala bentuk penderitaan, sembilan hal yang harus dihilangkan untuk mencapai realitas arahata phala yaitu nafsu, niat jahat, kebodohan, kemarahan, dendam, tidak berterimakasih, iri hati, kecemburuan, dan kepicikan. (A.IX.2).

Melihat pentingnya media tersebut, maka guru perlu menerapkan media dalam proses belajar mengajar di sekolah. Salah satu jenis media yang dapat diterapkan di dalam proses belajar mengajar yaitu media visual gambar. Media mempunyai fungsi yang sangat baik untuk 
meningkatkan hasil belajar maksimal (Daryanto, 2010: 3).

Hal tersebut juga ditemukan di Sekolah Dasar Negeri Gembongan 04, Kecamatan Ponggok Kabupaten Blitar Jawa Timur pada survei yang dilakukan oleh peneliti pada bulan Oktober 2013. Di sekolah tersebut, Guru pada mata pelajaran pendidikan agama Buddha belum menggunakan media visual gambar secara optimal, guru dalam menyampaikan materi hanya menggunakan metode ceramah, sehingga hasil belajar siswa belum maksimal.

Berdasarkan hasil wawancara dengan salah satu murid, bahwa proses belajar mengajar mata pelajaran pendidikan agama Buddha guru masih menjelaskan materi pembelajaran menggunakan metode ceramah, hanya monoton, Kegiatan pembelajaran yang kurang menyenangkan, menimbulkan motivasi yang kurang dalam pembelajaran. Guru menjelaskan hanya satu arah saja tidak terjadi umpan balik, Hal tersebut menjadikan siswa masih kurang aktif, dan lebih cenderung bermalas-malasan dan siswa kurang serius, tidak memperhatikan penjelasan materi yang disampaikan.

Melihat keadaan tersebut maka, peneliti menggunakan media visual gambar agar proses belajar mengajar menjadi lebih efektif, menarik, peneliti melakukan penelitian pada siswa kelas III Sekolah Dasar Negeri Gembongan 04 Kecamatan Ponggok Kabupaten Blitar Jawa Timur. Penelitian ini bertujuan untuk meningkatkan hasil belajar khususnya untuk siswa kelas III yang beragama Buddha, dengan menerapkan peranan media visual gambar.

\section{Rumusan Masalah}

Berdasarkan pada latar belakang masalahyang telah diuraikan, maka peneliti merumuskan masalah dalam penelitian ini adalah sebagai berikut:

1. Bagaimana peranan media visual gambar dalam proses belajar mengajar kelas III Sekolah Dasar Negeri Gembongan 04 Kecamatan Ponggok Kabupaten Blitar Jawa Timur?

2. Apakah media visual gambar dalam proses belajar mengajar dapat meningkatkan hasil belajar siswa kelas III Sekolah Dasar Negeri Gembongan 04 Kecamatan Ponggok Kabupaten Blitar Jawa Timur?

\section{Tinjauan Pustaka}

Oemar Hamalik (2003:155) mengatakan hasil belajar adalah sebagai terjadinya perubahan tingkah laku pada diri seseorang yang dapat di amati dan diukur bentuk pengetahuan, sikap dan keterampilan. Perubahan tersebut dapat diartikan terjadinya peningkatan dan pengembangan yang lebih baik sebelumnya yang tidak tahu menjadi tahu. Pengertian hasil belajar menurut A.J. Romizowski dalam (Asep jihad \& Abdul Haris, 2008: 14) hasil belajar adalah keluaran (outputs) yang berupa kinerja (performance) dari suatu sistem masukan informasi-informasi (input).

Seperti dalam Vatthupama sutta, Sang Buddha membabarkan tentang cara meninggalkan noda batin, pencapaian tingkat kesucian tercapai secara bertahap dengan mengetahui noda batin sebagai noda batin dan meninggalkannya, serta mengetahui bahwa noda batin telah ditinggalkan. Dengan meninggalkan dan telah meninggalkan kekotoran batin, orang memilik keyakinan kepada Buddha, Dhamma dan Sangha (M.I.203-204).

Andersen dalam (Harun Rasyid \& Mansur, 2007: 12) sependapat dengan Bloom bahwa 
karakteristik manusia meliputi cara yang tipikal dari berpikir, berbuat, dan perasaan. Tipikal berpikir berkaitan dengan ranah kognitif, tipikal berbuat berkaitan dengan ranah psikomotor dan tipikal perasaan berkaitan dengan ranah afektif. Ketiga ranah tersebut merupakan karakteristik manusia dan dalam bidang pendidikan ketiga ranah tersebut merupakan hasil belajar.

Menurut Muhhibin Syah (2010: 116-120) memahami perilaku hasil belajar terdapat faktorfaktor yang yang berpengaruh yang mengakibatkan perubahan-perubahan antara lain: Kebiasaan, keterampilan, pengamatan, berfikir asosiatif dan daya ingat, berpikir rasional dan kritis, sikap, inhibisi, apresiasi, dan tingkah laku afektif.

Menurut Nana Sudjana (2009: 130) faktor yang dapat menghambat hasil belajar yang dicapai siswa yang dipengaruhi oleh dua faktor utama, yaitu yang pertama faktor dari dalam diri siswa itu sendiri dan yang kedua faktor yang datang dari luar diri siswa itu sendiri atau faktor lingkungan.

a) Faktor Biologis (bersifat jasmani)

Hasil belajar dipengaruhi oleh kondisi biologis berupa kesehatan fisik, dan cacat tubuh. Kesehatan siswa setiap saat selalu berubah. Faktor biologis siswa yang dimaksud dalam hal ini adalah kondisi fisik siswa.

1) Kesehatan

Sehat berarti dalam keadaan baik, yaitu baik segenap badan beserta bagian-bagian yang lain atau bebas dari penyakit. Kesehatan adalah keadaan atau hal dalam kaitannya dengan kondisi badan yang sehat. Kesehatan siswa berpengaruh terhadap hasil belajar karena dengan kondisi fisik yang sehat memungkinkan siswa untuk melakukan kegiatan belajar dengan lebih aktif.

2) Cacat tubuh

Cacat tubuh adalah sesuatu yang menyebabkan kurang baik dan kurang sempurnanya anggota tubuh atau badan, seperti: buta, tuli, patah kaki, patah tangan, lumpuh dan lain-lain. Keadaan cacat tubuh juga mempengaruhi belajar. Siswa yang cacat belajarnya akan terganggu.

b) Faktor Psikologis (faktor kejiwaan)

Terdapat lima faktor psikologis yang mempengaruhi kuantitas dan kualitas hasil belajar siswa. Faktor-faktor tersebut meliputi intelegensi, sikap, bakat, minat, dan motivasi siswa.

1) Inteligensi

Intelegensi merupakan kecakapan atau kemampuan siswa untuk menghadapi dan menyesuaikan ke dalam situasi yang baru secara cepat dengan menggunakan konsepkonsep yang abstrak secara efektif, mengetahui relasi dan mempelajarinya dengan cepat. Intelegensi erat kaitannya dengan ingatan, perasaan, perhatian dan minat. Intelegensi merupakan salah satu aspek yang berpengaruh pada berhasil tidaknya seorang siswa dalam belajar (Slameto, 2003: 56).

2) Sikap

Sikap adalah gejala internal yang berdimensi aktif berupa kecenderungan untuk mereaksi atau merespons dengan cara yang relatif tetap terhadap obyek orang maupun barang baik secara positif dan negatif (Dimyati \& Mudjiono, 2009: 239).

3) Bakat

Bakat adalah adalah kemampuan potensial yang dimiliki seseorang untuk 
mencapai keberhasilan belajar yang akan datang. Bakat dapat diartikan kemampuan individu yang muncul untuk melakukan tugas tanpa banyak bergantung pada upaya pendidikan dan pelatihan (Muhibbin Syah, 2010: 133).

4) Minat

Minat berarti kecenderungan dan kegairahan yang tinggi atau keinginan yang terhadap sesuatu. Minat sangat bergantung pada faktor-faktor internal yaitu pemusatan perhatian, keingintahuan, motivasi, dan kebutuhan. Siswa yang memiliki minat terhadap suatu pelajaran akan mempelajari dengan sungguh-sungguh karena ada sesuatu yang menjadi daya tarik baginya (Muhibbin Syah, 2010: 134).

5) Motivasi

Motivasi adalah pendorong dalam usaha pencapaian tujuan. Setiap perbuatan yang dilakukan untuk mencapai tujuan yang selalu digerakkan oleh motivasi atau dorongan (Slameto, 2003: 58).

Seperti dalam Anangana Sutta noda diartikan sebagai keinginan-keinginan jahat dan tidak bajik. Keinginan tidak bajik adalah curang, licik, berbahaya, congkak, kosong, pribadinya takberisi, berlidah tajam, berbicara tanpa pikir mereka tidak terjaga di dalam kemampuan indera mereka, tidak sederhana dalam makan, tidak mengabdi untuk pencerahan, tidak peduli dengan kehidupan petapa, tidak memiliki rasa hormat terhadap pelatihan, bermewah-mewah, sembrono, pemimpin dalam menghasut, mengabaikan kesendirian, malas, tidak sepenuhnya sadar, tidak terkonsentrasi, pikirannya terkonsentrasi, pikirannya mengembara, kurang kebijaksanaan, orang yang ucapannya tidak berguna (M.I.25)
Menurut Sumiati dan Asra (2007: 161) Media visual gambar adalah jenis media pembelajaran yang menggunakan kemampuan indera mata atau penglihatan. Media visual gambar menghasilkan pesan berupa bentuk yang dapat dilihat. Dengan media visual gambar pengalaman belajar yang dialami siswa sangat tergantung pada kemampuan penglihatannya.

Pada zaman Sang Buddha, dalam Milinda Panha dikisahkan Sang Buddha menggunakan kekuatan supra normal dalam bentuk bayangan menunjukan gambar alat kelamin pria yang tersembunyi di balik selaput tipis untuk menyadarkan Brahmana Sela tentang Kebenaran (Lany Anggawati \& Wena Cintiawati, 2002: 9697).

Media visual gambar menyalurkan pesan dan informasi melalui simbol-simbol visual dalam berbagai bentuk antara lain :

a) Gambar

Gambar merupakanmedia grafis yang paling banyak digunakan. Gambar merupakan hasil lukisan yang menggambarkan orang, tempat dan benda dalam berbagai variasi orang, tempat dan benda dalam berbagai variasi (Cecep Kustandi \& Bambang Sutcipto, 2011: 45).

b) Foto

Hasil pemotretan atau fotografi menggunakan kamera foto. Sama seperti media gambar, foto merupakan media visual yang efektif, karena dapat memvisualisasikan objek dengan lebih konkret, lebih realistis dan lebih akurat (Daryanto, 2010: 108).

c) Grafik

Grafik adalah penggambaran sederhana suatu data kuantitatif secara akurat dalam bentuk yang lebih menarik dan mudah 
dipahami. Tampilan visual grafik juga lebih menarik bila dibandingkan data dalam bentuk tabel. Dengan mengalihkan data angka-angka ke dalam sebuah grafik, maka arti dari angkaangka tersebut menjadi jelas (Daryanto, 2010: 124-126).

d) Diagram/Skema

Diagram adalah gambar sederhana yang menggunakan garis dan simbol untuk menggambarkan struktur dari objek tertentu secara garis besar. Diagram adalah media yang biasanya digunakan untuk menerangkan satu proses, prosedur, letak bagian-bagian atau hubungan dengan bagian lain (Cecep Kustandi \& Bambang Sutcipto, 2011: 47).

e) Bagan (Chart)

Bagan adalah kombinasi antara media grafis, gambar dan foto yang dirancang untuk memvisualisasikan secara logis dan teratur mengenai fakta pokok atau gagasan (Nana Sudjana, 2009: 27).

f) Poster

Poster adalah media yang kuat dengan warna serta pesan dengan maksud menarik perhatian orang yang melihat pesan singkat, biasanya salah satu yang meyakinkan (Nana Sudjana, 2009: 51).

g) Sketsa

Sketsa merupakan media visual sederhana sebagai sarana yang paling singkat dan abstrak untuk menggambarkan suatu objek, untuk menambah pemahaman visual terhadap objek (Cecep Kustandi \& Bambang Sucipto, 2011: 46).

Menurut Gerlach \& Ely dalam (Daryanto, 2010: 10) fungsi media sebagai berikut :

a) Memperjelas penyajian pesan agar tidak terlalu verbalistis (dalam bentuk kata-kata tertulis atau lisan belaka).

b) Mengatasi keterbatasan ruang, waktu dan daya indra.

c) Dengan menggunakan media pendidikan secara tepat dan bervariasi dapat diatasi sikap pasif anak didik

d) Memungkinkan untuk belajar mandiri sesuai dengan bakat dan kemampuan visual.

e) Memberi rangsangan yang sama, mempersamakanpengalaman dan menimbulkan persepsi yang sama.

f) Proses pembelajaran mengandung lima komponen komunikasi, guru, bahan pelajaran media, siswa, dan tujuan pembelajaran.

Manfaat media pembelajaran yang telah terakumulasi dari beberapa pendapat pakar yang dirangkum oleh Azhar Arsyad (2010: 126) adalah sebagai berikut:

a) Penyampaian materi pembelajaran dapat diseragamkan.

b) Proses pembelajaran menjadi lebih jelas dan menarik.

c) Proses pembelajaran menjadi lebih interaktif.

d) Dengan media akan terjadinya komunikasi dua arah secara aktif, sedangkan tanpa media guru cenderung bicara satu arah.

e) Efisiensi dalam waktu dan tenaga.

f) Meningkatkan kualitas hasil belajar siswa.

g) Media memungkinkan proses belajar dapat dilakukan dimana saja dan kapan saja.

h) Media dapat menumbuhkan sikap positif siswa terhadap materi dan proses belajar.

i) Mengubah peran guru ke arah yang lebih positif dan produktif.

Unsur-unsur dalam media visual gambar yang disampaikan kepada siswa dapat dikembangkan dalam berbagai bentuk antara lain :

a) Kesederhanaan. 
b) Penekanan.

c) Keterpaduan.

d) Keseimbangan.

e) Bentuk.

f) Garis

g) Tekstur

h) Warna

Menurut Aristo Rahadi (2003: 27-28) ada lima syarat yang harus dipenuhi dalam menggunakan media gambar adalah sebagai berikut:

a) Autentik yaitu gambar harus secara jujur menggambarkan situasi atau peristiwa, jika siswa melihat langsung.

b) Sederhana yaitu komposisi gambar cukup jelas menunjukkan bagian-bagian pokok dalam gambar tersebut.

c) Ukuran gambar proporsional yaitu siswa mudah membayangkan ukuran sesungguhnya benda atau obyek yang digambar.

d) Memadukan antara keindahan dengan kesesuaiannya untuk mencapai tujuan pembelajaran.

e) Gambar harus jelas. Tidak setiap gambar yang bagus merupakan media yang bagus. Sebagai media yang baik, gambar hendaknya bagus sesuai dengan tujuan pembelajaran yang ingin dicapai.

Menurut Asnawir dan M. Basyirudin Usman (2002: 49) media visual gambar memiliki kelebihan yaitu

a) Gambar bersifat kongkrit dan realistis. Proses belajar mengajar dengan menggunakan media visual gambar lebih menunjukkan hal yang nyata dan menunjukkan pokok materi.

b) Gambar dapat mengatasi batas ruang dan waktu. Gambar dapat memberikan penjelasan tentang kejadian masa lalu. c) Gambar dapat mengatasi kekurangan daya maupun panca indera manusia. Gambar dapat membantu mengamati benda yang terlalu kecil maupun terlalu besar ukurannya.

d) Gambar dapat digunakan menjelaskan suatu masalah yang sulit dijelaskan agar tidak terjadi kesalahan.

e) Gambar harganya terjangkau dan mudah didapat. Gambar bisa didapat di majalah, buku, koran dan internet.

f) Gambar mudah digunakan baik siswa secara perorangan maupun digunakan dalam kelompok.

Menurut Asnawir dan M. Basyirudin Usman (2002:50) kelemahan media visual gambar adalah:

a) Gambar hanya menekankan pada persepsi indera penglihatan. Gambar tidak bisa digunakan untuk orang yang memiliki keterbatasan.

b) Gambar merupakan benda yang terlalu kompleks kurang efektif untuk kegiatan pembelajaran. Gambar cenderung akan membuat bosan, kurang memberikan suasana yang hidup.

c) Ukuranya sangat terbatas untuk kelompok besar. Gambar yang ukuranya kecil tidak memadai.

\section{METODE PENELITIAN}

Penelitian menggunakan kolaborasi yang mengutamakan kerjasama antara guru pendidikan agama Buddha di Sekolah Dasar tersebut dan peneliti. Menurut David Hopkins (dalam Masnur Muslich, 2011: 43) setiap siklus penelitian terdiri dari empat kegiatan yaitu perencanaan (planning), pelaksanaan (action), pengawasan (observe), dan refleksi (reflection). Pelaksanaan PTK ini dilakukan lebih dari satu siklus mengingat bahwa 
belum tentu satu siklus dapat memberikan hasil yang memuaskan.

Subjek penelitian dalam penelitian ini adalah siswa kelas III Sekolah Dasar Negeri Gembongan 04 Kecamatan Ponggok, Kabupaten Blitar Jawa Timur yang beragama Buddha tahun ajaran 2013/2014 yang dijadikan subjek penelitian sebanyak 7 siswa terdiri dari 5 siswa laki-laki dan 2 siswa perempuan.

Teknik pengumpulan data dalam penelitian ini adalah observasi, tes, dan wawancara. Observasi dilakukan pada saat proses pembelajaran agama Buddha dengan fokus mengamati pelaksanaan peranan media visual gambar oleh guru dan siswa dengan instrumen yang digunakan berupa lembar observasi. Tes dilakukan sebelum dan sesudah pelaksanaan tindakan. Sedangkan wawancara dilakukan kepada guru dan siswa setelah tindakan selesai dilakukan.

Data yang diperoleh dari penelitian hasil belajar sebelum penerapan media visual gambar adalah 7 siswa belum mencapai nilai tuntas (KKM) dan setelah penerapan diperoleh hasil belajar dari 7 siswa sudah mencapai nilai tuntas.

Instrumen pengumpulan data dalam penelitian ini, yaitu: pedoman observasi, pedoman tes, dan pedoman wawancara.

a) Pedoman observasi

Pedoman observasi ini memuat tentang lembar observasi dan hal-hal yang akan diamati pada saat pembelajaran dilakukan, yaitu aktivitas siswa dan guru berkenaan dengan penerapan peranan media visual gambar. Pada saat pembelajaran berlangsung, peneliti bertindak sebagai pengamat yang turut berpartisipasi aktif dengan siswa. b) Pedoman tes

Instrumen pengumpulan data yang kedua adalah pedoman tes. Pada pedoman tes ini memuat kisi-kisi soal dan butir-butir soal. Penelitian ini menggunakan tes uraian dengan jumlah 10 butir soal sehingga penskoran dengan cara pembobotan. Nilai hasil akhir test diambil dari nilai keseluruhan butir soal.

c) Pedoman wawancara

Instrumen pengumpulan data yang ketiga adalah pedoman wawancara dengan jenis terstruktur, yaitu jenis wawancara yang daftar pertanyaanya sudah disusun oleh peneliti sesuai dengan hal yang dibutuhkan oleh peneliti dalam sebuah penelitian (Masnur Muslich, 2013: 9). Pedoman ini memuat tentang pertanyaan-pertanyaan secara garis besar dan dikembangkan secara mendalam oleh peneliti. Wawancara dilakukan kepada responden yang terdiri dari guru pamong pendidikan agama Buddha dan siswa

\section{PEMBAHASAN}

\section{Hasil Analisis Data}

Nilai pre test siswa pada proses belajar di siklus I yaitu persentase $100 \%$ keseluruhan 7 siswa tidak tuntas dengan memperoleh nilai di bawah nilai KKM nilai rata-rata yang diperoleh dari 7 siswa adalah 49,29. Sedangkan nilai KKM yang ditentukan mata pelajaran pendidikan agama Buddha adalah 75.Nilai post test pada proses belajar di siklus I yaitu nilai persentase 42,86\%, 3 siswa tuntas dengan memperoleh nilai di atas KKM, sedangkan nilai persentase $57,14 \%$ dari 4 siswa yang tidak tuntas dengan memperoleh nilai di bawah KKM dan nilai rata-rata yang diperoleh adalah 77,42 . 
Tabel 1.

Hasil Ketuntasan Belajar Siklus I

Pre test

\begin{tabular}{|c|c|c|c|}
\hline No & Kriteria & Frekuensi & Persentase \\
\hline 1 & Tuntas & 0 & $0 \%$ \\
\hline 2 & $\begin{array}{c}\text { Tidak } \\
\text { tuntas }\end{array}$ & 7 & $100 \%$ \\
\hline
\end{tabular}

Post test

\begin{tabular}{|c|c|c|c|}
\hline No & Kriteria & Frekuensi & Persentase \\
\hline 1 & Tuntas & 3 & $42,86 \%$ \\
\hline 2 & $\begin{array}{c}\text { Tidak } \\
\text { tuntas }\end{array}$ & 4 & $57,14 \%$ \\
\hline
\end{tabular}

Sumber : Diolah Peneliti

Hasil observasi pembelajaran pada siklus I yaitu kemampuan guru dalam mengelola proses belajar mengajar sudah baik, yaitu menunjukkan persentase $72 \%$.

Tabel 2.

Hasil Observasi Pembelajaran Siklus I

\begin{tabular}{|l|c|c|c|}
\hline $\begin{array}{c}\text { Jenis } \\
\text { Observasi }\end{array}$ & $\begin{array}{c}\text { Skor } \\
\text { Maksi } \\
\text { mal }\end{array}$ & $\begin{array}{c}\text { Jumlah } \\
\text { Skor } \\
\text { Jawab } \\
\text { an }\end{array}$ & $\begin{array}{c}\text { Persentase } \\
\text { Siklus I }\end{array}$ \\
\hline $\begin{array}{l}\text { Observasi } \\
\text { Pembelajar } \\
\text { an Siklus I }\end{array}$ & 85 & 61 & $72 \%$ \\
\hline
\end{tabular}

Sumber : Diolah Peneliti

Hasil observasi pembelajaran pada siklus I yaitu kemampuan guru dalam mengelola proses belajar mengajar sudah baik, yaitu menunjukkan persentase $69 \%$.

Tabel 3.

Hasil Observasi Guru Siklus I

\begin{tabular}{|c|c|c|c|}
\hline $\begin{array}{c}\text { Jenis } \\
\text { Observasi }\end{array}$ & $\begin{array}{c}\text { Skor } \\
\text { Maksi } \\
\text { mal }\end{array}$ & $\begin{array}{c}\text { Jumlah } \\
\text { Skor } \\
\text { Jawaban }\end{array}$ & $\begin{array}{c}\text { Persenta } \\
\text { se } \\
\text { Siklus I }\end{array}$ \\
\hline $\begin{array}{c}\text { Observasi } \\
\text { Guru Siklus } \\
\text { I }\end{array}$ & 65 & 45 & $69 \%$ \\
\hline
\end{tabular}

Sumber : Diolah Peneliti
Nilai pre test siswa pada proses belajar $\mathrm{di}$ siklus II yaitu nilai persentase $71,43 \%$ dari 5 siswa sudah tuntas dengan memperoleh nilai di atas KKM, sedangkan $28,57 \%$ dari 2 siswa yang tidak tuntas dengan memperoleh nilai di bawah KKM dan nilai rata-ratanya yang diperoleh adalah 81,28. Nilai post test pada proses belajar mengajar di siklus II yaitu persentase $100 \%$ dari keseluruhan 7 siswa sudah tuntas dengan memperoleh nilai di atas KKM dan nilai rataratanya yang diperoleh adalah $92,43 \%$.

Tabel 4.

Ketuntasan Belajar Siklus II

Pre test

\begin{tabular}{|c|c|c|c|}
\hline No & Kriteria & Frekuensi & Persentase \\
\hline 1 & Tuntas & 5 & $71,43 \%$ \\
\hline 2 & $\begin{array}{c}\text { Tidak } \\
\text { tuntas }\end{array}$ & 2 & $28,57 \%$ \\
\hline
\end{tabular}

Sumber : Diolah Peneliti

Post test

\begin{tabular}{|c|c|c|c|}
\hline No & Kriteria & Frekuensi & Persentase \\
\hline 1 & Tuntas & 7 & $100 \%$ \\
\hline 2 & $\begin{array}{c}\text { Tidak } \\
\text { tuntas }\end{array}$ & 0 & $0 \%$ \\
\hline
\end{tabular}

Sumber : Diolah Peneliti

Berdasarkan hasil observasi pembelajaran pada siklus II yaitu kemampuan guru dalam mengelola proses belajar mengajar sudah baik, yaitu menunjukkan persentase $87 \%$.

Tabel 5.

Hasil Observasi Pembelajaran Siklus II

\begin{tabular}{|l|c|c|c|}
\hline \multicolumn{1}{|c|}{$\begin{array}{c}\text { Jenis } \\
\text { Observasi }\end{array}$} & $\begin{array}{c}\text { Skor } \\
\text { Mak } \\
\text { simal }\end{array}$ & $\begin{array}{c}\text { Jumlah } \\
\text { Skor } \\
\text { Jawaban }\end{array}$ & $\begin{array}{c}\text { Persentase } \\
\text { Siklus II }\end{array}$ \\
\hline $\begin{array}{l}\text { Observasi } \\
\text { Pembelajaran } \\
\text { Siklus II }\end{array}$ & 85 & 74 & $87 \%$ \\
\hline
\end{tabular}

Sumber : Diolah Peneliti

Berdasarkan hasil observasi pembelajaran pada siklus II yaitu kemampuan guru dalam 
mengelola proses belajar mengajar sudah baik, yaitu menunjukkan persentase $87 \%$.

Tabel 6.

Hasil Observasi Guru Siklus II

\begin{tabular}{|l|c|c|c|}
\hline \multicolumn{1}{|c|}{$\begin{array}{c}\text { Jenis } \\
\text { Observasi }\end{array}$} & $\begin{array}{c}\text { Skor } \\
\text { Maksimal }\end{array}$ & $\begin{array}{c}\text { Jumlah } \\
\text { Skor } \\
\text { Jawaban }\end{array}$ & $\begin{array}{c}\text { Persenta } \\
\text { se } \\
\text { Siklus II }\end{array}$ \\
\hline $\begin{array}{l}\text { Observasi } \\
\text { Guru Siklus } \\
\text { II }\end{array}$ & 65 & 54 & $83 \%$ \\
\hline
\end{tabular}

Sumber : Diolah Peneliti

\section{KESIMPULAN}

Berdasarkan hasil penelitian tindakan kelas yang dilaksanakan di Sekolah Dasar Negeri Gembongan 04, Kecamatan Ponggok, Kabupaten Blitar, Jawa Timur pada mata pelajaran pendidikan agama Buddha kelas III dapat dibuat kesimpulan sebagai berikut:

1. Pembelajaran pendidikan agama Buddha kelas III Sekolah Dasar Negeri Gembongan 04, Kecamatan Ponggok, Kabupaten Blitar materi hari raya agama Buddha dengan menggunakan media visual gambar mampu membuat siswa merasa senang dan lebih antusias atau bersemangat dalam mengikuti pembelajaran sehingga tujuan proses belajar mengajar tercapai secara efektif.

2. Berdasarkan penelitian tindakan kelas, hasil belajar siswa kelas III Sekolah Dasar Negeri Gembongan 04, Kecamatan Ponggok, Kabupaten Blitar dengan menggunakan media visual gambar pada mata pendidikan agama Buddha meningkat dari siklus I dan siklus II. Hasil belajar siswa tersebut meningkat pada siklus I yaitu $0 \%$ menjadi $43 \%$ menunjukkan peningkatan $43 \%$. Siklus II meningkat lagi dari $71 \%$ menjadi $100 \%$ hal ini menunjukkan peningkatan sebesar $29 \%$. Berarti media visual gambar dapat meningkatkan hasil belajar siswa kelas III Sekolah Dasar Negeri Gembongan 04 Kecamatan Ponggok, Kabupaten Blitar, jika digunakan dalam proses belajar.

\section{DAFTAR PUSTAKA}

Aditya Nagara. (2002). Kamus Praktis Bahasa Indonesia. Surabaya: Bintang Usaha Jaya.

Aditya Suharisman. http://eprints.uny.ac.id/3873/1/SKRIPSI_AND ITYAS_SUHARISMAN.pdfDiakses - pada tanggal 24 maret 2014, pada pukul 11.13 di Wonogiri.

Anggutara Nikaya (The Book of the Gradual Sayings) (Ones, Twos, Threes) Woodward, F. L. (Transl.). 1989. Oxford: Pali Text Society.

Asnawir \& M. Basyirudin Usman. (2002). Media Pembelajaran. Jakarta: Ciputat Press.

Asep Jihad \& Abdul Haris. (2008). Evaluasi Pembelajaran. Yogyakarta: Multi Pressindo.

Aristo Rahadi. (2003). Media Pembelajaran. Jakarta: Dikjen Dikti Depdikbud.

Azhar Arsyad. (2010). Media Pembelajaran. Jakarta: PT. Raja Gravindo Persada.

Cecep Kustandi \& Bambang Sutcipto. (2011). Media Pembelajaran Manual dan Digital. Jakarta: Ghalia Indonesia.

Daryanto. (2010). Media Pembelajaran Peranannya Sangat Penting Dalam Mencapai Tujuan Pembelajaran. Yogyakarta: Gava Media.

Dalyono. (2009). Psikologi Pendidikan. Jakarta: Rineka Cipta.

Dimyati \& Mudjiono. (2009). Belajar dan Pembelajaran. Jakarta: Rineka Cipta.

Djono R, Chosiyah, \& A. Syamsuri. (2001). Bimbingan dan Konseling Belajar. Surakarta: Universitas Sebelas Maret.

Dwi Winarno. (2006). Paradigma Baru Untuk Pendidikan Kewarganegaraan Panduan Perkuliahan di Perguruan Tinggi. Surakarta: PT Bumi Aksara.

Fuad Ihsan. (2005). Dasar-dasar Kependidikan. Jakarta. Rineka Cipta.

Harun Rasyid \& Mansur. (2007). Penilaian Hasil Belajar. Jakarta: CV. Wacana Prima.

Krisnanda Mukti Wijaya. (2003). Wacana Buddha Dhamma. Jakarta: Yayasan Dharma Pembangunan.

Lanny Anggawati \& Wena Cintiawati. (2000). Panduan Tipitaka Kitab Suci Agama Buddha. Klaten. Vihara Bodhivamsa. . (2002). Petikan Milinha Panha. Klaten: Wisma Meditasi Dhammaguna. 
(2003). Majjhima Nikaya (The Middle Length Sayings) Vol. II Horner, I.B. (Transl).. Oxford: PTS.

Masnur Muslich. (2013). Melaksanakan PTK itu Mudah. Jakarta: PT. Bumi Aksara.

Mohammad Asrori. (2007). Psikologi Pembelajaran. Bandung: CV. Wacana Prima.

Muhibin Syah. (2010). Psikologi Pendidikan. Bandung : PT Remaja Rosdakarya.

Nanamoli \& Bikkhu Bodhi. (Transl.). 2004. Majjhima Nikāya (The Middle Length Discourses of the Buddha) 1. Diterjemahkan ke Indonesia oleh Lanny Anggawati \& Wena Cintiawati Klaten: Vihāra Bodhivana \& Wisma Dhammaguna.

Nana Sudjana. (2009). Penilaian Hasil Proses Belajar Mengajar. Bandung: Remaja Rosdakarya.

(2013). Dasar-Dasar Proses Belajar Mengajar. Bandung: Sinar Baru Algensindo.

Ngalim Purwanto. (2007). Psikologi Pendidikan. Bandung: PT. Remaja Rosdakarya.

Oemar Hamalik.(2003). Proses BelajarMengajar. Bandung: PT Bumi Aksara.

Rusidi. 2009. UU Sisdiknas Pendidikan Umum dan pendidikan keagamaan. Jakarta: CV Naga Jawa Berdikari.

Slameto. (2003). Belajar dan Faktor-Faktor yang mempengaruhi. Jakarta: Rineka Cipta

Suharsimi Arikunto, Suhardjono, \& Supardi. (2012). Penelitian Tindakan Kelas. Jakarta: PT. Bumi Aksara.

Sumiati \& Asra. (2007). Metode Pembelajaran. Jakarta: CV. Wacana Prima.

Surya Widya. (2008). Dhammapada. Jakarta: Yayasan Abdi Dhamma Indonesia.

Syaiful Bahri Djamarah \& Zain Aswan. (2006). Strategi Belajar Mengajar. Jakarta: Rineka Cipta.

Undang-Undang No. 20 tahun 2013 tentang Sisdiknas dan Peraturan Pemerintah No.32 tentang Standar Pendidikan Nasional. 